\title{
Health of sexual minorities in north-eastern Brazil: representations, behaviours and obstacles
}

\author{
Cíntia de Lima Garcia ${ }^{1}$, Grayce Alencar Albuquerque ${ }^{2}$, Jefferson Drezett ${ }^{3}$, Fernando Adami ${ }^{4}$
}

DOI: http://dx.doi.org/10.7322/jhgd.110985

\begin{abstract}
Objective: The aim of this study was to identify the social representations (SR) of health and major inequities, obstacles and challenges experienced by lesbians, gays, bisexuals, and transgenders regarding access to health services.

Methods: This qualitative research was conducted with a group of sexual minorities recruited using the snowball technique. The data were organised according to Bardin and analysed from the perspective of SR.

Results: Twelve gays, nine transvestites, six lesbians and three bisexuals participated. Most believed health to be the absence of disease and indicated the group's vulnerability to sexually transmitted diseases. The search for health services was motivated by pathological symptoms or screening for sexually transmitted diseases. The difficulties were related to the deficiencies of the health service regarding prejudice.

Conclusions: The study population showed reductionist health representations, sought health services under the curative perspective and faced challenges/obstacles when accessing health services.
\end{abstract}

Keywords: minority health, homosexuality, sexually transmitted diseases, health inequalities, prejudice.

\section{INTRODUCTION}

Sexual minorities, including individuals who identify themselves as lesbian, gay, bisexual and transgender (LGBT) and those who are attracted to individuals of the same sex or same behaviours, are poorly studied in population-based samples with regard to health and inequalities in health ${ }^{1}$. Nevertheless, it is important to emphasise that the access to health care among sexual minorities is not properly explored in the literature. Available data indicate that inequalities, violations and obstacles due to heterosexual hegemony compromise LGBT access to health care ${ }^{2}$.

Brazilian studies in health facilities report discriminatory care, misconduct, constraints, prejudice and even verbal abuse by healthcare providers against LGBT individuals ${ }^{3,4}$. These negative experiences cause insecurity and impede them from looking for healthcare ${ }^{5}$.

As a result, complex health indicators are found in the group, such as a high occurrence of HIV/AIDS among transsexuals and men who have sex with men ${ }^{6}$, alarming global levels of mental disorders and suicide attempts among young and adult LGBT individuals ${ }^{7}$, an increased risk of using alcohol and psychoactive substances ${ }^{8}$, and an increased risk of obesity and cardiovascular disease among lesbian and bisexual women ${ }^{9}$.

Considering the context of restricted access to healthcare among this minority group, the following questions were raised and guided the present research: How does the LGBT population see health? In which situations does this population seek health services? What difficulties/obstacles do they face when searching for assistance?

The objective of this study was to analyse the social representations (SR) of LGBT individuals about health, as well as inequities, obstacles and challenges to accessing health services. Understanding this context is important for the formulation of strategies and policies to ensure the efficiency of assistance and the promotion of health for the LGBT group.

1 Mestre em Ciências da Saúde. Faculdade de Juazeiro do Norte (FJN) - Juazeiro do Norte (CE), Brasil.

2 Doutora em Ciências da Saúde. Universidade Regional do Cariri (URCA) - Crato (CE), Brasil.

3 Doutor em Ciências da Saúde. Núcleo de Programas Especiais - Serviço de Violência Sexual e Aborto Legal do Hospital Pérola Byington - Centro de Referência da Saúde da Mulher. São Paulo (SP), Brasil.

4 Doutor em Saúde Pública. Laboratório de Estudos e Escrita Científica do Departamento de Saúde Coletiva, Faculdade de Medicina do ABC (FMABC) - Santo André (SP), Brasil.

Corresponding author: Cintia de Lima Garcia. E-mail: cintiadelimagarcia@hotmail.com

Suggested citation: Garcia CL, Albquerque GA, Dresett J, Adami F. Health of Sexual Minorities in North-eastern Brazil: Representations, Behaviours and Obstacles. J Hum Growth Dev. 26(1): 94-100. Doi: http://dx.doi.org/10.7322/jhgd.110985

Manuscript submitted: Jan 15 2016, accepted for publication Feb 052016. 


\section{METHODS}

This descriptive, qualitative research was conducted with LGBT individuals residing in the Juazeiro municipality (CE), located in rural north-eastern Brazil between July and September 2013.

\section{Procedures}

A partnership was formed with the Cariri Support Group for Free Sexual Orientation (GALOSC), an institution in CE that militates on behalf of human rights for LGBT individuals. This institution provided the contact information of registered individuals who were then contacted via phone according to the technique of "chain of informants" or "snowball" 10 , by which each research participant indicates other potential participants.

After accepting and signing the informed consent form, participants were interviewed. Interviews were recorded on a digital media player, which totalled approximately 50 hours. A previously scheduled, semi-structured, individual interview was applied, which included questions about social, family and cultural trajectories, and as well as questions related to the main objectives of the study.

Data collection was interrupted after reaching the "theoretical saturation point"11, which occurs when new respondents begin to repeat the content already obtained in previous interviews without adding new or relevant information.

\section{Data analysis}

After interviews were fully transcribed, we used content analysis (CA), as proposed by Laurence Bardin. According to CA, the text is a means of expression of the subject, in which the analyst looks for categorising text units (words or phrases) that are repeated, implying an expression that represents them ${ }^{12}$.

The methodological theoretical framework was the theory of social representations (TSR) proposed by Moscovici in 1961. This social psychology theory emphasises socio-cultural and psychosocial aspects involving human behaviour ${ }^{13}$.

SR are socially-shared modes of knowing or representing and interacting with the world and everyday life, which is always present in an opinion, position, expression or posture of an individual in his/her everyday life ${ }^{14}$.

In this study, the TSR was applied to investigate perceptions, visions and behaviour with regard to health, given that they emerge from social constructs of life, knowledge and practises of subjects.

\section{Ethical and legal aspects}

The study was approved by the Ethics Committee of Human Research of the Faculty of Medicine of ABC, located in Santo André, protocol 200935.

\section{RESULTS}

We interviewed 30 individuals aged 18 to 51 years: most were male (80\%). Concerning sexual orientation, 12 (40\%) were gay, nine (30\%) transvestites, six (20\%) lesbians and three (10\%) bisexuals.
Participants were predominantly mixed (white and brown) (40\%), single (73\%) and from outlying areas of the city (86.6\%). As for the educational and professional trajectories, most had not completed high school (36.6\%) and worked in varied paid activities (80\%).

The exploration of the material allowed the identification of three predominant thematic dimensions: the first portrayed health as the absence of disease; the second showed LGBT health as linked to sexually transmitted diseases; and the third pointed to the group's access to health services marked by a curative approach and many obstacles. From this, it was possible to build the four categories shown below.

Health: "It's living well without being sick"

Several participants identified health as the mere absence of disease and as safe sexual practises:

Well, health for me is living well without being sick. (Gay, 27 years)

Health is having sex while using a condom. (Transvestite, 38 years)

Other participants, particularly transvestites, in addition to mentioning practising safe sex as a health concept, also said beauty was a prerequisite for health, which revealed the importance of aesthetics in their lives:

It is to wake up looking pretty every day ... have sex using a condom. That's what I think health is about. (Transvestite, 26 years)

Other comments indicated that seeing a doctor regularly was necessary for health, as follows:

It's being ok with yourself and seeing a doctor regularly. (Gay, 25 years)

A small number of respondents mentioned mental health, nutrition and education as requirements for good health:

Being healthy is being a physically, mentally and spiritually healthy person: when your body functions in a good and perfect way. (Gay, 39 years) It just depends on your diet, how you behave, and if you have a good education. (Lesbian, 22 years)

LGBT Health: the group's view

When asked about possible specificities of LGBT health, it was evident that the representations of the majority of subjects were focused on the risk of sexually transmitted diseases (STD)/AIDS, as respondents stated that a significant proportion of the homosexual population engaged in sexually risky behaviour, which resulted in a higher risk of contracting an STD:

Homosexual men have a higher risk of contracting a sexually transmitted disease because many people are unprepared, for example, having sex without using a condom, which leads to many sexually transmitted diseases. (Gay, 35 years) 
Others indicated that living conditions common to the group were involved in the transmission of STDs, such as factors that exposed them to risky situations. Subjects, according to the reports that follow, considered the marginalisation imposed on the group and the lack of opportunities to enter the labour market as the main causes for the use of alcohol and drugs, prostitution and, consequently, a greater vulnerability to STDs:

Homosexuals are more vulnerable because many are marginalised, and then many turn to alcohol, drugs, or prostitution. (Gay, 27 years)

The risk of homosexuals getting sick is greater. Due to the lack of employment opportunities, many transvestites decide to offer their services on the streets, and, as happened to others and myself, end up being forced to have sex without using a condom, thus contracting a disease. (Transvestite, 22 years)

Further, participants also mentioned prostitution as an alternative to achieving the idealised aesthetic; however, they made the risks involved clear, such as having unprotected sex:

People say 'go to São Paulo for three months and get breast implants.' In an instant, you can do it there ... Sometimes a man offers 100, 200, 300 'reais' to have sex with him without a condom. (Transvestite, 34 years)

“I don’t look for it often because I rarely get sick": the search for health services

Subjects were investigated concerning the search for health services, which enabled us to verify that most saw health facilities as a local service focused on the diagnosis and treatment of diseases, particularly STDs:

I don't go often because I don't get sick often; when I go, it is more for oral health procedures, infections, the flu and stuff like that. (Gay, 39 years)

I go every six months to get tested for HIV, syphilis and stuff like that. (Transvestite, 51 years)

Similarly, there was a statement made regarding looking for health services after exposure to a highrisk STD situation, in which the search for health services occurred after unprotected sex:

I search for it. Every month one has to go, sometimes once every three months; when I have sex with a man without using a condom, the nurse says I have to go at least every three months to check if there's anything wrong. (Transvestite, 31 years)

Others said they seek care regularly, but to treat an established disease:

Yes, because I am HIV-positive serostatus, I need treatment. (Gay, 36 years)
People said they also go to health units to obtain condoms; however, they mentioned their dissatisfaction with the number of delivered codons, given the amount that they needed:

I go to get condoms, but when I go, they give me only four or five, while sex professionals should get 25 to 30. (Transvestite, 26 years)

"It's crowded and everyone is looking": barriers to accessing health

When asked about possible difficulties faced by LGBT individuals in healthcare services, some pointed out crowding in the offices:

I think the difficulty is related to overcrowding. (Gay, 27 years)

Other respondents suggested the existence of a vicious circle: the individual does not seek health services, and health professionals are not aware of the group's needs:

How will I go to the healthcare unit if I'm not made aware that there is one and that it works? (...) And, how will a person deliver good care if he is not aware? (Lesbian, 22 years)

In addition, some reports indicated that some difficulties were related to professional practise, the unpreparedness of the professionals and the existence of discrimination as barriers to accessing health.

The difficulty lies in having trained professionals delivering care to the group, you know? So, if you do not get rid of your prejudices to take care of another person, it can get tricky; most will treat different people with negligence. (Bisexual, 28 years)

Unfortunately, LGBT individuals have great difficulty accessing healthcare, especially when they go to the health facility; they are discriminated against, and I have seen embarrassing situations. (Gay, 24 years)

On the other hand, the next participant did not look for assistance because of the shame felt when receiving unusual looks within the health units, which revealed the extent of social prejudice in the health sector:

No ... I am ashamed to be there because everyone is looking. (Transvestite, 33 years)

\section{DISCUSSION}

Simplistic SR of health, such as health referring to the absence of disease, were common in several interviewees. The comments on LGBT health were focused on STDs, reproducing the idea that the group's health was restricted to such diseases. Therefore, the search for health 
services was predominantly motivated by sickness, screening/diagnosis or treatment of STDs. It was also found that those who looked for health services faced obstacles, such as overcrowding, a complaint common to other population groups, as well as social and institutional prejudice.

These findings contrasted the current concept of health, in which the health-disease process resulted from the interaction among social, economic and environmental determinants and conditions, in opposition to a biomedical approach, which focused on pathological symptoms ${ }^{15}$.

The minority of research subjects understood health from a more holistic perspective, as only some participants discussed other aspects, such as mental balance, nutrition and education, as necessary conditions of being healthy.

There is a lack of studies on SR of health among sexual minorities. However, studies addressing other population groups revealed the predominance of the biomedical model in Brazilian health, and the prevalence of health still being seen as the mere absence of disease ${ }^{16}$.

Corroborating this evidence, a study conducted with users of a public health service in Rio de Janeiro emphasised the guarantee of access to medical consultations in the SR of health. This association is common in today's society, in which people generally seek health services due to pathological symptoms and find the solution to their main complaints during medical consultation ${ }^{17}$.

It seems that, regarding the SR of LGBT health, the majority of the subjects prioritised sexual behaviour and vulnerability to STDs. Undoubtedly, HIV/AIDS is a serious disease for some subgroups of LGBT people; however, large numbers of mental disorders, some types of cancer, obesity and cardiovascular disease are also highly reported among these minority populations ${ }^{18}$.

Several subjects characterised the group as partaking in unsafe sexual behaviours and having a high rate of HIV/AIDS. In this context, mapping was performed in bars and other homosexual hotspots in two neighbourhoods in the city of São Paulo, which showed that 52\% of men who had sex with men had sex without protection with stable partners, while $42 \%$ did so with occasional partners ${ }^{19}$.

In other countries, this problem persists. Research conducted in New York with 150 subjects newly diagnosed with HIV (95\% gay, 3\% bisexual men and 2\% transgenders) showed that $79 \%$ of the sample claimed to have unprotected anal $\operatorname{sex}^{20}$.

These data justified the presence of condom use in the health SR of the subjects, since recognising unsafe sexual behaviours among people in the group and the vulnerability to STDs made them aware of the possibility of having safe sex (using a condom).

However, scientific evidence showed that, despite having knowledge about STDs and ways of transmission and prevention, high rates of unprotected sex were reported among sexual minorities, particularly among gay and transgender individuals ${ }^{21,22}$.

Still concerning the vulnerability of LGBT individuals to STDs, subjects mentioned the use of alcohol and drugs as an aggravating factor, since the marginalisation experienced by the group was identified as a condition that enhanced the chances of unsafe behaviour. In fact, the literature showed higher rates of smoking, alcohol and illicit substance use among young and adult LGBT individuals compared to their heterosexual peers ${ }^{18}$.

Prejudice also influenced this scenario ${ }^{18}$, since homosexuality experience and gender expression, in contrast to biological sex, was marked by discrimination ${ }^{2}$. In this sense, an extensive literature review postulated that the internalised prejudice was related to the adoption of unsafe sexual behaviour by the group. The author gathered consistent data pointing to the existence of this influence, according to which, ironically, practises were associated with the internalisation of the homosexual as an AIDS spreader ${ }^{23}$.

In addition, the SR of the subjects pointed to the lack of opportunities in the labour market as the main cause of prostitution and, thus, of the higher risk of exposure to STDs. This idea was corroborated by a survey in a large city in the north-east Brazil with 110 transvestites, most of which (75.2\%) had low educational levels and were involved in prostitution $(71.8 \%)$. This revealed that the low educational attainment, together with the stigma and discrimination, hindered the entry of such people into the formal labour market, which made prostitution more likely to be their main source of income ${ }^{22}$.

It was noticeable in some comments that prostitution was often configured as an attractive way to achieve the idealised feminisation, where the exchange of sex, protected or not, for money ensured access to silicone prosthetics, which reconfigured the male body.

In this sense, the aesthetics and the body were central to the concerns of transvestites and transsexuals. The fight against biology using hormones, silicone, surgery and makeup made female characteristics flourish in their bodies $^{24}$.

These data were closely related to the appearance of beauty in health concepts of transvestites, since the SR were influenced by experiences shared in the environment, which were then taken and perpetuated as individual realities.

These data showed the vulnerability of LGBT health, which undoubtedly stemmed from the restricted access to health services of the group, and, particularly, to health promotion actions. This restricted access was observed in several comments, since most subjects saw health services under a curative perspective and looked for them only in the presence of pathological symptoms or when partaking in the screening/treatment of STDs.

Thus, one can see that the use of health services by the subjects was influenced by the SR of the group on health, which was predominantly seen as the absence of disease, and the perceptions about LGBT health, which were mostly focused on STDs (Figure 1).

However, the demand for health care, mediated only by pathological complaints or the search for a diagnosis, put the health of individuals at risk, which implied a limited access to health-promoting actions.

The only other reason participants included for seeking health services was the acquisition of condoms, even though subjects criticised the amount of condoms received because, as they said, it was insufficient, especially for those who were professional sex workers. 


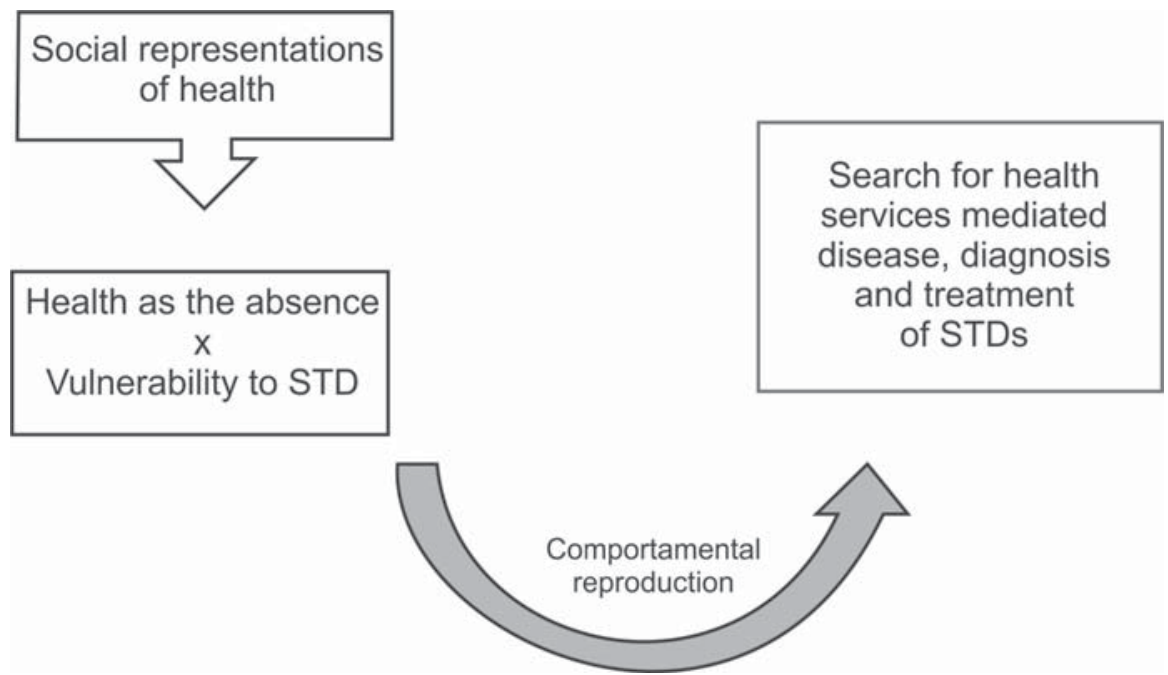

Figure 1: The influence of subjects' social representations in seeking health services. STD: sexually transmitted diseases.

This finding was common in other studies, such as Pimenta and Merchan-Hamann ${ }^{25}$, in which the respondents cited a limited access to condoms in primary healthcare units and, therefore, had to purchase their own protection.

These data revealed a major failure of health services in relation to the prevention of STDs, as the unavailability of condoms was one of the reasons for their non-use during sex ${ }^{19}$.

Regarding the demand for health services, among the six lesbians interviewed, there was no demand for preventive cervix and breast cancer screenings, for example. In Brazil and other countries, research revealed significant proportions of lesbians who did not undergo routine cervical cancer screenings ${ }^{3,26}$.

A survey conducted on homosexual and bisexual women in Brazil stated that the difficulties reported by the subjects concerning preventive examinations were discomfort and embarrassment related to gynaecological examinations, the lack of health services capable of dealing with particular demands of lesbian women, and the unpreparedness of health professionals towards the health needs of lesbians ${ }^{27}$.

Deficiencies in health services were also central in the statements of the subjects of this study, since comments criticised the health system, stating their dissatisfaction with the precariousness and inefficiency of the programmes, and institutional prejudice. Such issues were challenging for LGBT health, especially because they demotivated this group to look for health services.

Some participants revealed the existence of a vicious circle. On one hand, the user was not aware of the importance of health promotion services and, therefore, they were not sought; on the other hand, some professionals did not have the qualifications or the awareness necessary regarding LGBT health to attract the public to the health centres.

The unpreparedness of health professionals across the group was evidenced by other researchers in the area ${ }^{2-4}$. In addition, discrimination and social prejudice present in health services were characterised as major obstacles to accessing health in the LGBT population ${ }^{28}$.

Thus, the deficiency in welcoming this population in health services, coupled with inadequate programmes regarding the specificities of the group and professional approaches contaminated by erroneous and stereotypical perceptions, resulted in difficult access, disqualification of care $^{29}$ and the predictable exclusion of these groups from care actions and health promotion ${ }^{28}$.

It can be said without a doubt that prejudice and homophobia are factors that increase the vulnerability of LGBT individuals ${ }^{18}$, and that, in order to improve the health of this group, measures to reduce the effects of these inequities in LGBT populations should be conducted.

\section{Limitations}

The generalisation of these findings was questionable. The research was conducted with a small convenience sample of participants. While the method adopted for the recruitment of subjects made the research feasible, it also imposed limitations given that it was possible that we recruited the most visible subjects in society who were exposed to similar environmental conditions, which shaped and motivated their representations and experiences.

Nevertheless, the adoption of the snowball technique was justified because it was a complex and difficult social group to contact for scientific research. Furthermore, the data presented contributed to filling gaps on the subject and, therefore, to advancing the knowledge about the health of the LGBT group, which should help to make viable the expansion of healthcare access to the group.

\section{Final Remarks}

The analysis, from the perspective of SR, revealed that most of the subjects of this study showed reductionist views about health, referring to the absence of diseases, safe sex and access to medical appointments.

In addition, comments predominantly portrayed the group as being exposed to a greater risk of STDs, especially AIDS. The reasons for this increased risk ranged 
from unsafe sexual habits to vulnerable behaviours, such as drug use and prostitution.

Regarding access to health, the behavioural reproduction of the subjects' representations was evident, since most sought health services to screen and treat STDs and pathological symptoms.

Moreover, those seeking services or health care providers made important direct criticisms against the system and the treatment received, revealing the presence of obstacles often due to the still hegemonic heterosexuality, including in the health sector.
Therefore, the data presented here showed a population exposed to conditions and risk behaviours with limited views on health and still steeped in obstacles and social inequities, which raised questions regarding their accessibility to healthcare and the attention provided by health services.

Professionals and health services closer to the LGBT population are needed to establish more efficient and equitable attention on the group. Health facilities should prioritise care actions and health promotion in this group, enabling the reduction of damage to LGBT health.

\section{REFERENCES}

1. Strutz K, Herring A, Halpern C. Health disparities among young adult sexual minorities in the U.S. Am J Prev Med. 2015;48(1): 76-88. DOI: http://dx.doi.org/10.1016/j.amepre.2014.07.038

2. Lionço T. Que direito à saúde para a população GLBT? Considerando direitos humanos, sexuais e reprodutivos em busca da integralidade e da equidade. Saude Soc. 2008;17(2): 11-21. DOI: http://dx.doi. org/10.1590/S0104-12902008000200003

3. Barbosa RM, Facchini R. Acesso a cuidados relativos à saúde sexual entre mulheres que fazem sexo com mulheres em São Paulo, Brasil. Cad Saúde Pública. 2009;25(Supl. 2): 291-300. DOI: http://dx.doi. org/10.1590/S0102-311X2009001400011

4. Carvalho LS, Philippi MM. Percepção de lésbicas, gays e bissexuais em relação aos serviços de saúde. Universitas: Ciênc Saúde. 2013;11(2): 83-92. DOI: http://dx.doi.org/10.5102/ucs.v11i2.1837

5. Brotman S, Ryan B, Jalbert Y, Rowe B. The impact of coming out on health and health care access: The experiences of gay, lesbian, bisexual and two-spirited people. J Health Soc Policy. 2002;15(1): 1-29. DOI: http://dx.doi.org/10.1300/J045v15n01_01

6. Malta M, Magnanini MM, Mello MB, Pascom AR, Linhares Y, Bastos FI. HIV prevalence among female sex workers, drug users and men who have sex with men in Brazil: a systematic review and meta-analysis. BMC Public Health. 2010;10: 317. DOI: http://dx.doi.org/10.1186/1471-2458-10-317

7. Haas AP, Eliason M, Mays VM, Mathy RM, Cochran SD, D'Augelli AR, et al. Suicide and suicide risk in lesbian, gay, bisexual, and transgender populations: review and recommendations. J Homosex. 2011;58(1): 10-51. DOI: http://dx.doi.org/10.1080/00918369.2011.534038

8. Goldberg S, Strutz KL, Herring AA, Halpern CT. Risk of substance abuse and dependence among young adult sexual minority groups using a multidimensional measure of sexual orientation. Public Health Rep. 2013;128(3): 144-52.

9. Fredriksen-Goldsen KI, Kim HJ, Barkan SE, Muraco A, Hoy-Ellis CP. Health disparities among lesbian, gay, and bisexual older adults: results from a population-based study. Am J Public Health. 2013;103(10): 1802-9. DOI: http://dx.doi.org/10.2105/AJPH.2012.301110

10. Semaan S, Lauby J, Liebman J. Street and network sampling in evaluation studies of HIV risk-reduction interventions. Aids Rev. 2002;4(4): 213-23.

11. Fontanella BJ, Luchesi BM, Saidel MG, Ricas J, Turato ER, Melo DG. Amostragem em pesquisas qualitativas: proposta de procedimentos para constatar saturação teórica. Cad Saúde Pública. 2011;27(2): 388-94. DOI: http://dx.doi.org/10.1590/S0102311X2011000200020

12. Caregnato RC, Mutti R. Pesquisa qualitativa: análise de discurso versus análise de conteúdo. Texto Contexto Enferm. 2006;15(4): 679-84. DOI: http://dx.doi.org/10.1590/S0104-07072006000400017

13. Martins AM, Carvalho CA, Antunes-Rocha MI. Pesquisa em representações sociais no Brasil: cartografia dos grupos registrados no CNPq. Psicol Teor Prát. 2014;16(1): 104-14. DOI: http://dx.doi. org/10.15348/1980-6906/psicologia.v16n1p104-114

14. Lefevre F, Lefevre AM. Discourse of the collective subject: social representations and communication interventions. Texto Contexto Enferm. 2014;23(2): 502-7. DOI: http://dx.doi.org/10.1590/010407072014000000014

15. Brasil. Ministério da Saúde. Secretaria de Vigilância em Saúde. Secretaria de Atenção à Saúde. Política Nacional de Promoção da Saúde. 3.ed. Brasília: Ministério da Saúde; 2010.

16. Câmara AM, Melo VL, Gomes MG, Pena BC, Silva AP, Oliveira KM, et al. Percepção do processo saúde-doença: significados e valores da educação em saúde. Rev Bras Educ Med. 2012;36(1): 40-50. DOI: http://dx.doi.org/10.1590/S0100-55022012000200006

17. Veloso RC, Ferreira MA. Saúde e serviços: relações estabelecidas com os usuários à luz das representações sociais da cidadania. Rev Enferm UERJ. 2013;21(1): 60-5. 
18. Institute of Medicine (IOM). The health of lesbian, gay, bissexual, and transgender people. Building a foundation for better understand. Washington: National Academies Press; 2011.

19. Antunes MC, Paiva VS. Territórios do desejo e vulnerabilidade ao HIV entre homens que fazem sexo com homens: desafios para a prevenção. Temas Psicol. 2013;21(3): 1125-43. DOI: http://dx.doi.org/10.9788/ TP2013.3-EE17PT

20. Drabkin AS, Sikkema KJ, Wilson PA, Meade CS, Hansen NB, DeLorenzo A, et al. Risk patterns preceding diagnosis among newly HIV-diagnosed men who have sex with men in New York City. AIDS Patient Care STDS. 2013;27(6): 333-41. DOI: http://dx.doi.org/10.1089/apc.2012.0313

21. Guimarães MDC, Ceccato MGB, Gomes RRFM, Rocha GM, Camelo LV, Carmo RA, et al. Vulnerabilidade e fatores associados a HIV e sífilis em homens que fazem sexo com homens, Belo Horizonte, MG. Rev Méd Minas Gerais. 2013;23(4): 412-26. DOI: http://www.dx.doi.org/10.5935/2238-3182.20130067

22. Sousa PJ, Ferreira LOC, Sá JB. Estudo descritivo da homofobia e vulnerabilidade ao HIVIAids das travestis da Região Metropolitana do Recife. Ciênc Saúde Coletiva. 2013;18(8): 2239-51. DOI: http://dx.doi. org/10.1590/S1413-81232013000800008

23. Nunan A. Preconceito internalizado e comportamento sexual de risco em homossexuais masculinos. Psicol Argum. 2010;28(62): 247-59.

24. Souza MH, Signorelli MC, Coviello DM, Pereira PP. Itinerários terapêuticos de travestis da região central do Rio Grande do Sul, Brasil. Ciênc Saúde Coletiva. 2014;19(7): 2277-86. DOI: http://dx.doi. org/10.1590/1413-81232014197.10852013

25. Pimenta FA, Merchan-Hamann E. Uso dos serviços de saúde por parte de homens que fazem sexo com homens do Distrito Federal. Tempus Actas Saúde Coletiva. 2011;5(4): 35-53. DOI: http://dx.doi. org/10.18569/tempus.v5i4.1056

26. Tracy JK, Lydecker AD, Ireland L. Barriers to cervical cancer screening among lesbians. J Womens Health (Larchmt). 2010;19(2): 229-37. DOI: http://dx.doi.org/10.1089/jwh.2009.1393.

27. Carvalho PMG, Nóbrega BSM, Rodrigues JL, Almeida RO, Abdalla FTM, Nichiata LYI. Prevention of sexually transmitted diseases by homosexual and bisexual women: a descriptive study. Online Braz J Nurs. 2013;12(4): 931-41. DOI: http://dx.doi.org/10.5935/1676-4285.20134177

28. Brasil. Ministério da Saúde. Política nacional de saúde integral de lésbicas, gays, bissexuais, travestis e transexuais. Brasília: Ministério da Saúde; 2010.

29. Albuquerque GA, Garcia $\mathrm{CL}$, Alves MJH, Queiroz CMHT, Adami F. Homossexualidade e o direito à saúde: um desafio para as políticas públicas de saúde no Brasil. Saúde Debate. 2013;37(98): 516-24. DOI: http://dx.doi.org/10.1590/S0103-11042013000300015

This article is distributed under the terms of the Creative Commons Attribution 4.0 International License (http://creativecommons.org/licenses/by/4.0/), which permits unrestricted use, distribution, and reproduction in any medium, provided you give appropriate credit to the original author(s) and the source, provide a link to the Creative Commons license, and indicate if changes were made. The Creative Commons Public Domain Dedication waiver (http://creativecommons.org/publicdomain/zero/1.0/) applies to the data made available in this article, unless otherwise stated.

\section{Resumo}

Objetivo: O objetivo deste estudo foi identificar as representações sociais (RS) das desigualdades na saúde e grandes, obstáculos e desafios vividos por lésbicas, gays, bissexuais, transgêneros e sobre o acesso aos serviços de saúde.

Método: pesquisa qualitativa foi realizada com um grupo de minorias sexuais recrutados por meio da técnica de bola de neve. Os dados foram organizados de acordo com Bardin e analisados sob a perspectiva da SR.

Resultados: Doze gays, nove travestis, seis lésbicas e bissexuais três participaram. A maioria acreditava saúde para ser a ausência de doença e indicou a vulnerabilidade do grupo para as doenças sexualmente transmissíveis. A busca por serviços de saúde foi motivada por sintomas patológicos ou rastreio de doenças sexualmente transmissíveis. As dificuldades estavam relacionadas com as deficiências dos serviços de saúde sobre o preconceito.

Conclusões: A população de estudo apresentou representações de saúde reducionistas, procuraram os serviços de saúde sob a perspectiva curativa e enfrentou desafios / obstáculos no acesso aos serviços de saúde.

Palavras-chave: saúde minoria, homossexualidade, doenças sexualmente transmissíveis, as desigualdades na saúde, preconceito. 